\title{
BIOACTIVE MONOTERPENES FROM ANTARCTIC PLOCAMIUM CARTILAGINEUM
}

\author{
JUANA ROVIROSA ${ }^{1}$, AGNES SOLER ${ }^{3}$, VANESSA BLANC', RUBÉN LEÓN $N^{3}$ AND \\ AURELIO SAN-MARTÍN ${ }^{* 1,2}$
}

\author{
${ }^{1}$ Universidad de Chile, Facultad de Ciencias, Depto. de Química, Casilla 653, Santiago, Chile. \\ ${ }^{2}$ Facultad de Ciencias, Universidad de Magallanes, Chile. \\ ${ }^{3}$ Department of Microbiology, DENTAID S. L, Barcelona, España. \\ (Received: July 18, 2013 - Accepted: October 18, 2013)
}

\begin{abstract}
In a chemical analysis of the red seaweed Plocamium cartilagineum collected in Antarctic Peninsula, four polyhalogenated monoterpenes were isolated. Their structures were established by spectroscopic techniques. Two of them are acyclic monoterpenes and the others are cyclic. We report the antimicrobial, insecticide and acaricide activities of compounds.
\end{abstract}

Keywords: Algae, Plocamium cartilagineum, Antarctic, monoterpenes

\section{INTRODUCTION}

Species of the genus Plocamium constitute a rich source of acyclic and cyclic halogenated monoterpenes. The red alga Plocamium cartilagineum (Dixon), of worldwide occurrence, has been shown to elaborate several structures of this type. Is a rich source of halogenated monoterpenes of cyclic, acyclic, and oxacyclic skeletons $\mathbf{s}^{1,2,3}$. It is common in species of genus Plocamium to find metabolites with a high degree of halogen incorporation, usually up to 5 halogens, in a skeleton having only 10 carbon atoms. In addition P. cartilagineum shows the largest variation in composition of monoterpenes as a function of geographical location ${ }^{4}$. Compounds from several Plocamium have been shown to exhibit insecticide activity and growth inhibitory activity against some insects ${ }^{5,6,7}$. In the course of our research program of the natural products chemistry of marine organisms from the Chilean and Antarctic coasts, now we isolated four polyhalogenated monoterpenes from P. cartilagineum collected in Bahia Fildes, Antarctic Peninsula. In the present study, two compounds (1, 2) were subjected to an insecticidal screening and one (4) was tested against oral bacteria.

\section{EXPERIMENTAL}

General procedures. - IR spectra were obtained with a Perkin-Elmer 1650/ FTIR spectrometer. NMR spectra were recorded on a Bruker AMX - 400 spectrometer, operating at 300 and $75.0 \mathrm{MHz}$ for ${ }^{1} \mathrm{H}$ and ${ }^{13} \mathrm{C}$ respectively, with TMS as on internal reference. EIMS and HRMS spectra were taken on a Micromass Q-Tof micromass Spectrometer. Liquid chromatography over silica gel Merck was performed in a medium pressure. HPLC was run on a Waters instrument equipped with a differential refractometer. Spots were visualized under UV light irradiation and by spraying $10 \% \mathrm{H}_{2} \mathrm{SO}_{4}$ in methanol solution, followed by heating.

Collection and extraction.- Plocamium cartilagineum (Dixon) was collected by Scuba diving $(-15 \mathrm{~m})$ at Bahia Fildes, Antarctic Peninsula. A voucher specimen $\left(\mathrm{N}^{\circ} 13032\right)$ is deposited in the herbarium of Facultad de Ciencias, Universidad de Chile. The alga ( $820 \mathrm{~g})$ was air-dried, ground and extracted with $n$-hexane exhaustively. The solvent was then removed at reduced pressure, affording an oily extract. The crude extract was chromatographed by open and medium pressure $\mathrm{CC}$ on silica gel using $n$-hexane containing increasing amounts of EtOAc as eluent. From the fractions eluted with $n$ - hexane were further separated by repeated MPLC on silica gel. This procedure yielded pure samples of the known polyhalogenated hydrocarbons $1,2,3$ and 4 .

Compound 1. - Colourless oil. IR $v \mathrm{~cm}^{-1}: 3105,3058,1661,1445,1235$, 922, 816. ${ }^{1} \mathrm{H}-\mathrm{NMR} \delta: 1.25(3 \mathrm{H}, \mathrm{s}), 2.35(1 \mathrm{H}, \mathrm{d}, J=14.4 \mathrm{~Hz}), 2.20-2.45(2 \mathrm{H}$, $\mathrm{m}), 2.61(1 \mathrm{H}, \mathrm{d}, J=14.4 \mathrm{~Hz}), 4.31\left(1 \mathrm{H}, \mathrm{dd}, J=11.4 ; \mathrm{J}^{\prime}=4.1 \mathrm{~Hz}\right), 4.72(1 \mathrm{H}$, brs), $4.91(1 \mathrm{H}, \mathrm{s}) .5 .16(1 \mathrm{H}, \mathrm{s}), 6.00(1 \mathrm{H}, \mathrm{d}, J=12.0 \mathrm{~Hz}), 6.06(1 \mathrm{H}, \mathrm{d}, J=$ $12.0 \mathrm{~Hz}) .{ }^{13} \mathrm{C}-\mathrm{NMR}\left(\mathrm{CDCl}_{3}\right) \delta: 26.4(\mathrm{Me}), 41.2\left(\mathrm{CH}_{2}\right), 41.4\left(\mathrm{CH}_{2}\right), \quad 43.4(\mathrm{C})$, 61.4(CH), 63.1(CH), 115.3( $\left(\mathrm{CH}_{2}\right), 120.2(\mathrm{CH}), 134.0(\mathrm{CH}), 142.2(\mathrm{C})$. EIMS $m / z$ : 242, 240, $238[\mathrm{M}]^{+}, 207,205,203,169,167,105,91$.

Compound 2.- Colourless oil. IR $v \mathrm{~cm}^{-1}: 3125,3053,1615,1435,924$, 790; ${ }^{1} \mathrm{H}$ NMR $\left(\mathrm{CDCI}_{3}\right) \delta: 1.75(3 \mathrm{H}, \mathrm{s}), 3.83(2 \mathrm{H}, \mathrm{s}), 3.95(2 \mathrm{H}, \mathrm{s}), 4.48(1 \mathrm{H}, \mathrm{dd}$, $J=6.0 ; 1.5 \mathrm{~Hz}), 6.16-6.11(2 \mathrm{H}, \mathrm{m}), 6.15(1 \mathrm{H}, \mathrm{d}, J=13.0 \mathrm{~Hz}), 6.44(1 \mathrm{H}, \mathrm{d}, J=$
$13.0 \mathrm{~Hz}) ;{ }^{13} \mathrm{C}-\mathrm{NMR}\left(\mathrm{CDCl}_{3}\right) \delta: 25.4(\mathrm{Me}), 37.3\left(\mathrm{CH}_{2}\right), 49.7\left(\mathrm{CH}_{2}\right), 67.4(\mathrm{CH})$, 68.8(s), 70.2(C), 122.6(CH), 130.3(CH), 133.5(CH), $134.8(\mathrm{CH}) ; \mathrm{MS} \mathrm{m} / \mathrm{z}: 357$, $355,353,351,\left(\mathrm{M}^{+}-\mathrm{CI}\right), 123,125,127,\left(\mathrm{C}_{4} \mathrm{H}_{5} \mathrm{Cl}_{2}^{+}\right), 77$.

Compound 3.-Colourless oil. IR $v \mathrm{~cm}^{-1}: 3500,3100,2950,1730,1630$, $1440,1390,980,950,850 .{ }^{1} \mathrm{H}-\mathrm{NMR}\left(\mathrm{CDCl}_{3}\right) \delta: 1.43(\mathrm{~s}, 3 \mathrm{H}), 3.83(\mathrm{~s}, 2 \mathrm{H}), 3.95$ $(\mathrm{s}, 2 \mathrm{H}), 4.33(\mathrm{dd}, 1 \mathrm{H}, J=6.0 ; 1.6 \mathrm{~Hz}), 5.92(\mathrm{~d}, 1 \mathrm{H}, J=13.0 \mathrm{~Hz}), 6.00-6.25(\mathrm{~m}$, $2 \mathrm{H}), 6.36(\mathrm{~d}, 1 \mathrm{H}, \quad J=13.0 \mathrm{~Hz}) .{ }^{13} \mathrm{C}-\mathrm{NMR}\left(\mathrm{CDCl}_{3}\right) \delta, 25.8(\mathrm{Me}), 37.6\left(\mathrm{CH}_{2}\right)$, $49.8\left(\mathrm{CH}_{2}\right), 69.3(\mathrm{CH}), 76.1(\mathrm{C}), 121.3(\mathrm{CH}), 132.9(\mathrm{CH}), 134.8(\mathrm{CH}) . \mathrm{MS} \mathrm{m} / \mathrm{z}$ : $368,370,372\left(\mathrm{M}^{+}\right), 230,149,107,105$.

Compound 4.- Colourless oil,; IR $v \mathrm{~cm}^{-1}: 3015,2350,1445,1378,1045$ ${ }^{1} \mathrm{H}-\mathrm{NMR}\left(\mathrm{CDCl}_{3}\right) \delta: 1.74(\mathrm{~s}, 3 \mathrm{H}), 1.82(\mathrm{~s}, 3 \mathrm{H}), 2.47(\mathrm{~m}, 2 \mathrm{H}), 3.48$ (brs, $\left.1 \mathrm{H}\right)$, $3.81(\mathrm{~d}, 1 \mathrm{H}, \mathrm{J}=10.8 \mathrm{~Hz}), 4.28(\mathrm{~d}, 1 \mathrm{H}, \mathrm{J}=10.8 \mathrm{~Hz}), 4.79(\mathrm{~d}, 1 \mathrm{H}, \mathrm{J}=9.4 \mathrm{~Hz}), 5.67$ $(\mathrm{d}, 1 \mathrm{H}, \mathrm{J}=9.4 \mathrm{~Hz}), 5.82(\mathrm{t}, 1 \mathrm{H}, \mathrm{J}=7.0) .{ }^{13} \mathrm{C}-\mathrm{NMR}(\mathrm{CDCl} 3) \delta: 11.2(\mathrm{Me}), 26.0$ $(\mathrm{Me}), 32.2(\mathrm{CH} 2), 45.2(\mathrm{CH}), 51.1(\mathrm{CH} 2), 72.5(\mathrm{CH}), 72.9(\mathrm{C}), 73.5(\mathrm{CH})$, $129.5(\mathrm{CH}), 134.9(\mathrm{C})$. MS $m / z: 378,380,382,384,359,361,363,365,315$, $317,319,321$

Bacterial strains.- Compound $\mathbf{4}$ was evaluated in vitro for antibacterial activity against the following nine oral bacteria: Streptococcus mutans NCTC 10449, Lactobacillus casei ATCC 393, Prevotella intermedia NCTC 13070, Veillonella parvula NCTC 11810, Campylobacter rectus NCTC 11489, Fusobacterium nucelatum DSMZ 20482, Agreggatibacter actinomycetemcomitans NCTC 10981, Parvimonas micra DSMZ 20468 and Porphyromonas gingivalis ATCC 33277.

Liquid cultures were prepared from single colonies transferred to modified brain heart infusion (brain heart infusion broth $[37 \mathrm{~g} / \mathrm{L}]$, mucin from porcine stomach type III [Sigma-Aldrich Chemie $\mathrm{GmbH}$, Buchs, Switzerland] [2.5 $\mathrm{g} / \mathrm{L}]$, yeast extract $[1 \mathrm{~g} / \mathrm{L}], \mathrm{L}$-cysteine $[0.1 \mathrm{~g} / \mathrm{L}]$, sodium bicarbonate $[2 \mathrm{~g} / \mathrm{L}]$ and supplemented with hemin $[5 \mathrm{mg} / \mathrm{L}]$, menadione $[1 \mathrm{mg} / \mathrm{L}]$, and glutamic acid $[0.25 \%])$ and grown anaerobically at $37^{\circ} \mathrm{C}$.

For the antimicrobial susceptibility test, the bacterial strains were grown in non-selective blood agar plates (No. 2 of Oxoid; Oxoid Ltd, Basingstoke, UK), with $5 \%$ defibrinated horse blood, hemin $(5 \mathrm{mg} / \mathrm{L})$ and menadione $(1 \mathrm{mg} / \mathrm{L})$ and incubated at $37^{\circ} \mathrm{C}$ under anaerobic conditions.

Antimicrobial susceptibility testing.- A solution of $\mathbf{4}$ was prepared at a final concentration of $400 \mathrm{mg} / \mathrm{mL}$ with dimethyl sulfoxide (DMSO) as solvent. Antimicrobial activity test was carried out according to Kirby-Bauer disc diffusion method $^{8}$. Three discs were applied with sterile forceps on the plate surface after the inoculation of $100 \mu \mathrm{L}$ of each bacterial strain in $\log$ phase. Then, 20 $\mu \mathrm{L}$ of the $\mathbf{4}$ solution was impregnated into the disc. The other discs were impregnated with $20 \mu \mathrm{L}$ of sterile MilliQ water and $20 \mu \mathrm{L}$ of $0.12 \%$ chlorhexidine $(\mathrm{CHX})$ and $0.05 \%$ cetylpiridinium chloride (CPC) mouthwash as negative and positive controls respectively. After 24-48 h of incubation the inhibition zone was measured in $\mathrm{mm}$ with a vernier caliper.

Biological activities.-In the insecticide/acaricide screen, the untreated and solvent controls were replicated x 10 . Insecticide standards were applied at three rates and replicated three times. Standards are selected because they are contemporary products that are commonly used in the field to control the pests tested in this screen. Eight insect/mite species were tested (see Table 1). All of these bioassays were designed to detect contact and ingestion activity. One non-traditional bioassay using the fall armyworm (Spodoptera frugiperda) is 
also included: antifeedant (ANTIF) test measuring feeding deterrence and suppression. The age/stages of insect tested were $3^{\text {rd }}$ instar fall armyworm and southern rootworm, immature and adult aphids and adult two-spotted spider mites. Fourth instar armyworm were used in the antifeedant bioassay. In the delayed toxicity/growth regulant test, fall armyworm that survives the acute toxicity test were transferred to untreated diet and held through at least one moult. Antifeedant activity was evaluated at $24 \mathrm{~h}$ and acute toxicity at $48 \mathrm{~h}$. All experimental compounds were formulated in a solvent of acetone-water (3:1) at a single, unreplicated rate of $1000 \mathrm{ppm}$. Formulated compounds were applied by a hydraulic belt sprayer.

\section{RESULTS AND DISCUSSION}

Plocamium cartilagineum (L.) Dixon (Plocamiaceae, order Plocamiales) was collected at Antarctic Peninsula. From the crude extract, after chromatography and successive gel filtration and HPLC, compound 1, 2, 3 and 4 were isolated (see Figure 1). The major component isolated was $\mathbf{2}$ (acyclic monoterpene), together with small amounts of $\mathbf{1 , 3}$, and $\mathbf{4}$, all of them were identified by comparison of its physical and spectroscopic properties with that reported in the literature ${ }^{9,10,11,12}$. This is the first report of $\mathbf{4}$ in a sample of Antarctic $P$. cartilagineum

We studied the antifeedant effects of two polyhalogenated monoterpenes (1 and 2) against several diverse insects' species. Table 1 summarizes the insecticidal activities of two compounds. The compound 1 showed the most potent anti-insect activity (see table 1) between the two compounds tested, mainly against Heliothis virescens (tobacco budworm). Compound $\mathbf{2}$ showed a mild activity towards the southern corn rootworm, Diabrotica undecimpunctata. The small amount obtained from compound $\mathbf{3}$ is not allowed to biological tests.

In the antimicrobial activity assay, $\mathbf{4}$ was active in all the oral species tested. Porphyromonas gingivalis and Parvimonas micra were the more susceptible species tested and Agreggatibacter actinomycetemcomitans and Lactobacillus casei the less susceptible (see Table 2). By first time the activity of a halogenated monoterpene against oral microorganisms is reported.<smiles>C=C1C[C@](C)(/C=C/Cl)[C@H](Cl)C[C@H]1Cl</smiles>

1<smiles>[R]C(C)(/C=C/Cl)C(Cl)/C=C/C(Cl)(CCl)CBr</smiles>

$2 \quad \stackrel{\mathrm{R}}{\mathrm{Cl}}$<smiles>CC1=CC[C@@H](C(C)(Cl)CCl)OC1C(Br)Br</smiles>

4
Figure 1. Compounds isolated from P. cartilagineum

Table 1. Insecticidal/acaricide activities of Plocamium cartilagineum compounds 1 and 2 .

\begin{tabular}{|c|c|c|c|c|c|c|c|c|c|c|c|}
\hline \multirow[b]{2}{*}{ Compound } & \multirow[b]{2}{*}{$\mathrm{ppm}$} & \multirow[b]{2}{*}{ FAW } & \multirow[b]{2}{*}{ DET } & \multicolumn{2}{|c|}{ Antifeed } & \multirow[b]{2}{*}{ ECB } & \multirow[b]{2}{*}{ SCRW } & \multirow[b]{2}{*}{ TSSM } & \multirow[b]{2}{*}{ BW } & \multirow[b]{2}{*}{ ALH } & \multirow[b]{2}{*}{ BBA } \\
\hline & & & & SUP & TBW & & & & & & \\
\hline 1 & 1000 & 40 & 46 & 31 & 80 & 0 & 0 & 9 & 0 & 20 & 12 \\
\hline 2 & 1000 & 0 & 28 & 35 & 30 & 0 & 60 & 7 & 0 & 20 & 24 \\
\hline
\end{tabular}

Results are reported on a scale of 0-100\%; 0: no activity;-100: complete mortality. Species: FAW: Fall Armyworm mortality (Spodoptera frugiperda); Antifeed DET: Fall Armyworm, Antifeedant Test-Deterrence; Antifeed SUP: Fall Armyworm, Antifeedant Test-suppression. TBW: Tobacco Budworm mortality (Heliothis virescens); ECB: European corn-.borer mortality $(\mathrm{Os}$ trinia nubilalis); SCRW: Southern corn rootworm (Diabrotica undecimpunctata); TSSM: Two spotted spider mite mortality (Tetranychus urticae); BW: Boll weevil mortality (Anthonomus grandis); ALH: Aster leafhopper mortality (Macrosteles pac(rons); BBA: Black bean aphid mortality (Aphis fabae). The standard used for each insect were: FAW: methomyl; TBW: fenvalerate; ECB: permethrin; SCRW: carbofuran; TSSM: cyhexatin; BW: azinphosmethyl; ALH: carbofuran; BBA: pirimicarb. All the standards showed $100 \%$ of activity.
Table 2.- Zones of inhibition of $\mathbf{4}$ (dissolved in DMSO) against nine oral bacterial species.

\begin{tabular}{|c|c|}
\hline Species & Zones of inhibition $(\mathbf{m m} \pm \mathbf{S D})$ \\
\hline S. mutans & $9.65 \pm 0.71$ \\
\hline L. casei & $8.90 \pm 1.12$ \\
\hline P. intermedia & $13.9 \pm 1.87$ \\
\hline V. parvula & $11.9 \pm 1.69$ \\
\hline C. rectus & $12.10 \pm 0.89$ \\
\hline F. nucleatum & $10.6 \pm 0.56$ \\
\hline A. actinomycetemcomitans & $8.40 \pm 1.53$ \\
\hline P. micras & $15.85 \pm 1.72$ \\
\hline P. gingivalis & $19.35 \pm 0.95$ \\
\hline Positive control & \\
\hline
\end{tabular}

* Corresponds to the mean value obtained for the nine species

\section{CONCLUSIONS}

The halogenated metabolites of Plocamium cartilagineum collected in Antarctica shown antimicrobial and insecticide activities. Previously it had been shown similar activities in other metabolites from this alga collected in different places of the Chilean coast ${ }^{13,14}$ and also halogenated monoterpenes had cytotoxic activity ${ }^{15}$. Our results confirm the importance of $P$. cartilagineum as a source of bioactive compounds regardless of the place of collection of the alga.

As a microbial growth inhibitor, could be interesting to test $\mathbf{4}$ activity in oral biofilm structures.

\section{ACKNOWLEDGEMENTS}

We thank to E.I. Du Pont de Nemours and Company, Stine-Haskell Research Center, Agricultural Products, Newark, USA, for carry out the insecticide/acaricide screen. This work was supported by Instituto Antártico Chileno (Proyecto INACH T_15-09).

\section{REFERENCES}

1. S. Naylor, F. Hanke, L. Manes, P. Crews, Prog. Chem. Org. Nat. Prod. 44,189 (1983).

2. J. Blunt, B. Copp, M. Munro, P. Northcote, M. Prinsep, R. Nat. Prod. Rep. 20 (2003).

3. A. Diaz-Marrero, J. Rovirosa, J. Darias, A. San-Martín, M. Cueto, J. Nat. Prod. 65, 585 (2002).

4. A. San-Martín, J. Rovirosa, Biochem. Syst. Ecol. 14, 459 (1986).

5. K. Watanabe, M. Miyakado, N. Ohno, A. Okada, K. Yanagi, K. Moriguchi, Phytochem. 28, 77 (1989).

6. P. Crews, B. Myers, S. Naylor, E. Clason, R. Jacobs, G. Staal, Phytochem. 23, 1449 (1984).

7. V. Argandoña, T. del Pozo, A. San Martín, J. Rovirosa, J. Chil. Chem. Soc. 45, $371(2000)$

8. AW. Bauer, WM. Kirby, JC. Sherris, M.Turck, Am. J. Clin. Pathol. 45, 493 (1966).

9. D. Stierle, R. Wing, J. Sims, Tetrahedron, 35, 2855 (1979).

10. J. Rovirosa, I. Sanchez, Y. Palacios, J. Darias, A. San-Martín, J. Chil. Chem. Soc. 35, 131 (1990).

11. D. Stierle, J. Sims, Tetrahedron, 35, 1261 (1979).

12. M. Cueto, J. Darias, J. Rovirosa, and A. San-Martín. J. Nat. Prod. 61, 1466 (1998).

13. V. Argandoña, J. Rovirosa, A. San-Martín, A. Díaz, A. Guadaño, A. Gonzalez-Coloma, J. Agric. Food. Chem, 50, 7029 (2002).

14. J. Rovirosa, R. Negrete, A. San-Martín, Phytochem. 30, 2165 (1991).

15. C. De Inés, V. Argandoña, J. Rovirosa, A. San-Martín, A. Díaz-Marrero, M. Cueto, A González-Coloma, Z. Naturforsch. 59 c, 339 (2004). 